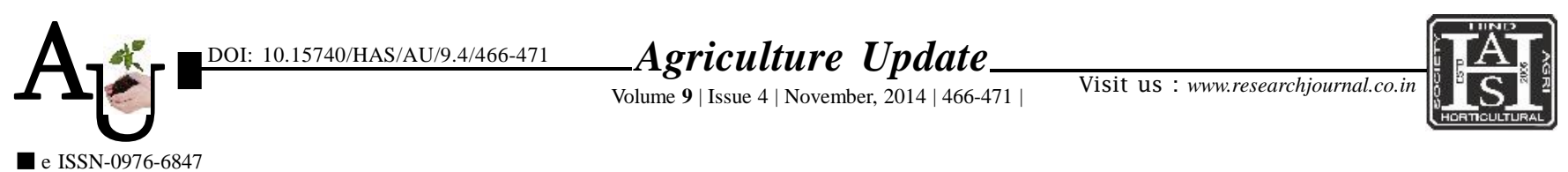

\title{
Research Article Influence of poultry wastes composts on the growth and yield attributes of maize
}

\author{
Article Chronicle : \\ Received : \\ 31.07.2014; \\ Revised : \\ 18.08.2014; \\ Accepted : \\ 03.09.2014
}

\section{PRASANTHRAJAN, P. DORAISAMY, M. PANDIYAN AND K.P. SIVAKUMAR}

SUMMARY : A field experiment was conducted with twelve treatments to test the effectiveness of different poultry - carbonaceous wastes compost on the soil properties, growth and yield attributes of maize (Hybrid Samrat). The application of compost improved the soil fertility by adding humus and available plant nutrients. Compost application along with 100 per cent and 75 per cent level of recommended NPK increased the growth and yield of maize. Among the different compost (Poultry droppings and coir pith, poultry droppings and paddy straw, poultry droppings and coir pith with rock phosphate), the compost prepared by mixing poultry droppings, coir pith and rock phosphate performed superior over others. The maize crop recorded high yield when grown using coir pith and rock phosphate added poultry compost along with recommended levels of NPK which was at par with the results of coir pith mixed poultry compost along with 75 per cent levels of recommended $\mathrm{N}, \mathrm{P}$ and $\mathrm{K}$. The present study confirmed that the compost application not only improved the maize yield but also the fertility status of soil and saved 25 per cent of fertilizer.

How to cite this article : Prasanthrajan, M., Doraisamy, P., Pandiyan, M. and Sivakumar, K.P. (2014). Influence of poultry wastes composts on the growth and yield attributes of maize. Agric. Update, 9(4): 466-471.

KEY Words:

Poultry waste,

Compost,

Maize yield,

Soil properties 